\title{
Climate Change Inaction and Optimism
}

\author{
Philip J. Wilson (1)
}

check for updates

Citation: Wilson, P.J. Climate Change Inaction and Optimism. Philosophies 2021, 6, 61. https:// doi.org/10.3390/philosophies6030061

Academic Editor: Nicholas Maxwell

Received: 26 May 2021

Accepted: 21 July 2021

Published: 23 July 2021

Publisher's Note: MDPI stays neutral with regard to jurisdictional claims in published maps and institutional affiliations.

Copyright: (C) 2021 by the author. Licensee MDPI, Basel, Switzerland. This article is an open access article distributed under the terms and conditions of the Creative Commons Attribution (CC BY) license (https:// creativecommons.org/licenses/by/ $4.0 /)$.
Independent Researcher, Kent CT18 8EN, UK; philip@pwarb.com

\begin{abstract}
The problem of climate change inaction is sometimes said to be 'wicked', or essentially insoluble, and it has also been seen as a collective action problem, which is correct but inconsequential. In the absence of progress, much is made of various frailties of the public, hence the need for an optimistic tone in public discourse to overcome fatalism and encourage positive action. This argument is immaterial without meaningful action in the first place, and to favour what amounts to the suppression of truth over intellectual openness is in any case disreputable. 'Optimism' is also vexed in this context, often having been opposed to the sombre mood of environmentalists by advocates of economic growth. The greater mental impediments are ideological fantasy, which is blind to the contradictions in public discourse, and the misapprehension that if optimism is appropriate in one social or policy context it must be appropriate in others. Optimism, far from spurring climate change action, fosters inaction.
\end{abstract}

Keywords: cognitive weakness; moral hazard; optimism; climate delay; tragedy of the commons

\section{Introduction}

In 1946 Karl Popper gave a talk entitled 'Are there philosophical problems?' chaired by Ludwig Wittgenstein. Popper argued that there really are philosophical problems while Wittgenstein regarded them as mere linguistic entanglements. Exchanges became vehement, the latter using a poker to emphasize his assertions. In Popper's version of events, in reply to Wittgenstein's challenge to name a real moral rule, he replied 'Not to threaten visiting guests with pokers' [1]. In the case of climate change, the semantic latitude of 'optimism' facilitates continued inaction. The prevailing usage of the word obscures the absence of much constructive scholarship or policy, a sometimes deliberate linguistic entanglement to which a spirited reaction would be entirely understandable.

Before arriving at optimism, with its associated discourse of human frailty, climate change inaction has been described as 'wicked', and approached as a collective action problem. These diverse themes are clarified by reference to holism, which shows that what applies to one level of a social hierarchy need not apply to another.

\section{Wickedness}

Problems of social policy are 'wicked' when approaches to them cannot be said to be correct or incorrect, as in societies in which diverse social groups have different priorities. Climate change inaction is sometimes said to be wicked [2,3], to mean effectively insoluble.

Wicked problems are difficult to define because there is no end to the relevant influences [4]. For instance, the problem of poverty involves the determinants of low income: poor education, housing, mental health, etc., but which is to receive attention first? If mental health, then what aspect-the number of clinics, the number of nurses, their training, etc.? Approaches to a (tame) technical problem are more or less correct; approaches to a wicked problem are not more or less correct, just more or less effective. Rittel and Webber [4] conclude that to promote one vision of goodness over another, in a society in which values and preferences vary, is a matter of politics. Some policies at the highest (political) levels of the hierarchy (the properly wicked ones) have no reliable degree of 
correctness and so are beyond the reach of systematic scholarship, and any moral aspect is also problematical.

Climate change inaction is in no way related to this. The burning of fossil fuels is directly relevant whatever the level, and while courses of remedial action might be intractable, their effectiveness or otherwise would not be difficult to discern. From the highest level of the hierarchy (the UN contemplating the will of sovereign countries) to the lowest (the individual), they can be denominated as greenhouse gas emissions. In relation to the practical problem of climate change inaction, wickedness is unconstructive.

\section{Holism}

The fact that society is hierarchical helps to clarify the notion of wickedness; members of an organization tend to see problems at a level below their own, and the higher the level the broader and more general the problems become. This is the concept of holism, by which a hierarchical entity is more than the sum of its parts. To illustrate, a square drawn with a pencil on a piece of paper consists of dark graphite particles on the surface of the paper, none of which are square or have anything to do with a square; the square is an emergent property [5]. Similarly, an array of dots may vary in size and shape, while in a zoomed-out image the same array can be seen to be part of a newspaper picture of a human face [6].

The study of a phenomenon at the level of its simplest constituents may elucidate ultimate mechanism but cannot take account of emergence. As the psychologist J.B. Watson is reputed to have said: 'The behaviourist cannot find consciousness in the test tube ...'. Understanding at one level is incomplete if it cannot be related to the adjoining levels. It might be trivial if unable to explain the higher level (analogous to just studying the dots of an image), or superficial if unable to give significance to the lower level (by not realizing that an image is made up of dots).

\section{Collective Action Problems}

Climate change inaction has been seen as a collective action problem, in which all parties would be better off cooperating but fail to do so because their individual interests, particularly the pursuit of individual profit, conflict with the common interest. For instance, free riders can benefit from public goods (roads, medical services, etc.) without paying for them, provided enough other people do pay.

Many papers have been written modelling such problems in game theory [7], which formalizes any activity in which one person's prediction of what another person will do affects what the first decides to do. In a well-known example, two prisoners do not cooperate even though it appears to be in their best interests to do so. Cooperation is formally illogical when the game is played a single time, that is, when it is not known whether the other party can be trusted, but trust and other emergent phenomena (duty, filial attachment, etc.) can influence repeated games, when more cooperative strategies are often best, especially when played among the individuals of a population [8].

Free riding is said to be an important constraint to effective climate action, requiring the actions of nations to be monitored and either sanctioned or rewarded [9]. The Kyoto Protocol did indeed pretend sanction for slow progress, but it was to do this through mechanisms (such as emissions trading) that were designed to 'leave stable doors open' [10]. Its salient characteristic was that it allowed everybody to free ride indefinitely, and to that extent the only collective action was to render the United Nations process ineffectual by not taking it seriously.

\section{The Tragedy of the Commons}

The tendency for a natural resource whose ownership is undefined (such as fresh water in an aquifer or ocean fishing grounds) to be over-exploited is a particular kind of collective action problem known as a tragedy of the commons [11]. The atmosphere is an example of a commons because emitting waste greenhouse gases and other pollutants into 
it has a collective cost not directly borne by the individual emitter. Overuse of the resource leads to collapse, as in some early civilizations [12].

Garrett Hardin envisaged that common land, over which there are communal rights, would be overgrazed as individual herdsmen increased the size of their herds for personal gain at the expense of others [11], but for centuries, common grazing land in England was managed according to detailed rules of the local court that limited the number of animals, hours of pasturing, etc. [13], and many other commons and resources with communal tenure have been and still are managed in such a way. Such institutions (neither the state nor the market) can govern with reasonable success, provided there is a willingness to make them work, and free riding is discouraged by regulation or customary practice [7].

According to Kenneth Binmore, one of the architects of game theory, 'A player in the human game of life is not some abstract entity called "everybody". We are all separate individuals, each with our own aims and purposes [and] if we pretend otherwise we have no hope of ever getting to grips with the tragedy of the commons' [14]. In fact, with this reductive outlook, the tragedy of the commons cannot even be addressed; it yields the rational self-interest of orthodox economics.

In what is called a richer theoretical model of climate change policy [9], diverse interests create new economic winners and losers, or 'distributive conflicts', by which economic criteria such as joint goods and preference heterogeneity provide the incentive for climate change action [15]. However, this is merely to recognize what is actually happening; it makes business-as-usual look respectable.

For economists, collective action problems reduce efficiency and can be optimized using the strategies of game theory. However, in a crucial but often overlooked distinction, a tragedy of the commons leads to collapse. To apply game theory to a tragedy of the commons is to disregard that foreknowledge.

The tragedy of the commons is a logical fundamental of climate change inaction. It is not to be confused with other collective action problems, nor can its salience be diminished by economics, nor is it a colloquialism [16]. However, it has not overcome climate change inaction, and to that extent it is inconsequential.

In the absence of more effectual scholarship, policy-makers and commentators dwell on various weaknesses to which the public is said to be susceptible, according to which the public is to be shielded from the truth and an optimistic tone adopted to encourage positive action.

\section{Cognitive Weakness}

Since the time of the Ancient Greeks, it has been noticed that we tend to believe what we want to believe, known recently as motivated reasoning, and sometimes said to complicate attitudes to climate change. Our beliefs are part of our identity, and those about ourselves are particularly unreliable. According to the Dunning-Kruger effect, we are generally overconfident in the correctness of our judgements and rate ourselves as more competent than we really are, especially if we lack competence. In the related Lake Wobegon effect, named after the fictional community in the stories by Garrison Keillor where all the children were above average, $94 \%$ of university professors thought they were better at their jobs than their average colleagues. We believe our own behaviour to be strongly influenced by external causes while we think that of others is due more to their underlying personality traits. Some people believe in the probability of an event by the vividness with which they can imagine it. False memories can be created by suggestion. And, an inability to find causes for important events leads to mental discomfort [17]. Francis Bacon (1561-1626) identified various other cognitive impediments including making general inferences from limited observation and explaining something by reference to a familiar pattern, and a further serious impediment is the tendency to dichotomy [18].

According to Mikael Klintman [19], the impediments are due to the fact that humans are deeply irrational. If to be rational or irrational is to rely on evidence or instinct, respectively, a combination of the two is generally helpful in making decisions that require 
judgement [20]. However, as correctness becomes increasingly problematical, instinct perforce has the stronger influence, and in relation to political belief it was all the stronger (through motivated reasoning) in the politically sophisticated [21]. That education should somehow increase intellectual laxity or bigotry illustrates the fallacy. To seek support for preconceived ideas in such a context is not to be irrational. It merely shows that political belief and other such attitudes have little if any degree of correctness. There is no need to imply that we are incapable of thinking straight.

\section{Moral Hazard}

Moral hazard arises when someone is tempted to take risks knowing that others will suffer the consequences. The term was introduced by the insurance industry for relatively careless behaviour among those insured. In the financial industries, it is the temptation to seek high returns by taking greater risks than are prudent, provided someone else pays when things go wrong [22].

Climate change action is susceptible to moral hazard for several reasons. The effects will be felt mainly by future generations; the scale is global so that national-scale action for most nations will have little material effect; to curb consumption in richer countries would be unpopular; the problem has scientific and ethical as well as personal and political aspects, and this complexity and novelty lend themselves to weakness of will and procrastination [23]; if the problem is recognized, we do not want to be reminded of our part in it [24]; while it looms so dangerously over our future, we are desperate to believe in miracles [25].

Such desperation easily slips into thinking that climate change will hit hardest somewhere else or that sooner or later something will turn up, and is sometimes given a veneer of respectability by speculative reference to future technological innovation. Negative emission technologies (the removal of carbon dioxide from the air), which are supposed to compensate for the lack of action to reduce emissions now, involve such extreme wishful thinking that they have been called carbon unicorns [26]. The writer Elizabeth Kolbert observed that 'We're used to the Hollywood ending ... Oh, you know, at the last minute something comes and saves us' (cited in [27]).

\section{Human Frailty}

Our intellectual and moral weaknesses are supposed to have so blighted our collective character that we are unable to face up to climate change, and instead the inaction is due to a failure to engage our emotions [28]. It is often argued that to be truthful about near-future climate change would be to engender fatalism and despair on the part of the public, or that the truth should be withheld to save face or maintain a united front [29]. Chris Stark, chief executive of the Committee on Climate Change, exemplifies the view: 'I think at the moment there is only one theory of change, which is that we need to frighten people somehow, you know that kind of question about how someone responds to stress, and I think if you frighten someone too much you get a really poor outcome...' [30]. David Attenborough's BBC documentary Extinction-the Facts was more sombre in mood than his previous portrayals of the apparently untouched natural world, and the BBC's head of natural history commissioning said: 'I thought the [viewing] figures would just go off a cliff'. Instead, the opposite happened [31].

Despite the lack of evidence, the theme of frailty endures. For instance, the emotional and psychological implications of climate change must be handled sensitively by highly skilled individuals or teams informed by social science scholarship [32]. The forthright Wallace-Wells [33] was accused of terrifying or depressing readers and of being unethical in exploring the scarier trajectories of climate change. We are said to be prone to eco-anxiety, 'a psychological disorder afflicting individuals who worry about the environmental crisis', giving rise to panic attacks, loss of appetite, irritability and insomnia [34]. Similarly, we shy away from the prospect of sacrifice and catastrophe, and the anticipatory worry causes mental distress including denial [35]. To accept that better tomorrows will not come is akin 
to a terminal prognosis [36], and if the topic of global warming is raised at a dinner party it goes down with a thud [37].

Perhaps the real disorder is in having an uneasy conscience (which, after Nietzsche, is a kind of illness), and perhaps those free of it simply have more pressing things to worry about.

\section{Alarm, Fear, Despair}

Climate scientists have admitted alarm for decades (the first recorded use of 'climate catastrophe' was in 1986 [38]), and are sometimes frank that we should be alarmed: 'Be alarmed, and let the alarm galvanize action. It is time for some healthy and realistic alarmism' [39]. Those wishing to prolong climate delay might accuse environmentalists of crying wolf, but to create a sense of urgency there would seem to be little alternative but to be alarming. As Donella Meadows put it: 'If a red light blinks on in a cockpit, should the pilot ignore it until it ... speaks in an unexcited tone? ... If it did, would anyone pay attention?' [40].

Sensational or shocking representations of climate change are said to induce fear and despair, but while they catch the attention [41], the prevailing reactions are related most closely to helplessness because the audience cannot see what they personally can do. For instance, the rhetoric of crisis does little to encourage participation and practical action [42]. Fear-arousing approaches to climate change have proved ineffectual or counter-productive because the audience feels disempowered without the means to deal with the problem [43]. And research by the Institute for Public Policy Research concluded that alarmism is unlikely to encourage behaviour change because the scale of the problem excludes the possibility of real action [44].

A difficulty with alarmist expression is that (after a time) it is suspected of exaggeration, damages trust or becomes laughable [41]. For formerly good evolutionary reasons, most humans have a limited attention span to devote to non-immediate problems [43].

\section{Terror}

Some commentators say they are more or less terrified by climate change [2]. Presumably, this shift from alarm to terror is hyperbole, but Mike Hulme prefers the literal interpretation [2]. Countdown clocks, for instance stating that the world has until 2030 before reaching $1.5^{\circ} \mathrm{C}$ of global warming, far from leaving audiences feeling nonplussed as the previous section suggests, 'might unleash wider fears and anxieties about the future, invoking a state of terror about climate change that could paralyse critical thinking, as in the reckless decision to invade Iraq after the events of $9 / 11^{\prime}$ [2]. Such manipulation of the language is easy to overlook: any action said to be too little too late 'evokes fear and can result in a paralysing state of shock and resignation' [45].

There is a gulf in meaning between a resigned helplessness and paralysing terror, but even if the latter were true, it would be largely immaterial because it relates to commentators citing each other. There is no evidence that the public really is terrified or despairing. To argue that it is either reflects a faulty view of the public or is a tactic to prolong climate delay. It is the dubious ground, together with the notions of human frailty already discussed, for shielding the public from the truth.

\section{Suppression of Truth}

According to Anthony Giddens, 'All governments ... [will have to try to] foster a more widespread consciousness of the need for [climate] action' [46]. Yet, the opposite is seen. Instead of using its diverse powers to nudge the public towards accepting that the demand for energy must decrease, the government of the United Kingdom suppresses the truth. It boasts that it has done more than most to reduce greenhouse gas emissions, citing territory emissions (which exclude imports, aviation and shipping) as though they are the total, when in fact they are about $60 \%$ of the total, and the main reason they have gone down since Kyoto is the decline of domestic industry and the consequent increase in imports. It 
is apparently satisfied with the UN-mediated process despite the absence of meaningful progress over five decades, and its claims to climate leadership, having outsourced the UK's emissions to the very countries supposedly being led, are bogus. There are many other examples, but in short, as Dieter Helm said at the time he was Chair of the Natural Capital Committee, '... rather than boast of their achievements, our political leaders should hang their heads in shame' [47]. The European Union similarly games the system [48]; according to critics, its strategic environmental agenda until 2024 is just a collection of buzzwords [49].

The extent to which the dishonesty is deliberate depends on the weight given to ideological fantasy.

\section{Ideological Fantasy}

A psychoanalytical approach to the study of subjectivity in capitalist ideology, attributed to the philosopher Slavoj Žižek, suggests that subjects respond to gaps between the real and symbolic (i.e., their ideology) with fantasy [50]. The approach reveals blindness in international development discourse [51] as well as in carbon offsetting, eco-tourism and philanthropic capitalism, and shows how these endure despite the contradictions that they persistently disavow [50].

The UN's Sustainable Development Goals are a case in point. The three pillars of sustainable development, economic development, social development and environmental protection, are described by Jeffrey Sachs (an architect of the goals) as 'mutually reinforcing' [52], but the mutual reinforcement is in fact contradiction insofar as economic and social development increase human environmental impact (which is already excessive). It overlooks the adverse consequences of continuing and largely unrestrained growth, especially in rich countries. In [52], the first example Prof. Sachs gives of technological innovation helping to achieve sustainable development is the maglev train taking people at $200 \mathrm{mph}$ between Shanghai and its international airport. This implied promotion of air travel would be difficult to understand without recourse to ideological fantasy or something similar.

To be disabused of ideological fantasy could be traumatic [50], so victims could be said to be mentally ill, or they might have decided that more information will not improve the chances of getting a problem right, which is to have a closed mind. This, according to the definition of David Krakauer, is to be stupid [53]. Or if the fantasists are boomers (Jeffrey Sachs is singled out), they might have confused their generation's values for universal ones [54].

Whatever the terminology, ideological fantasy is a serious mental impediment (worse and more consequential than any weakness of the public mind), while merely hoping for the best is the often-endearing trait of optimism.

\section{The History of Optimism}

In the present context the term 'optimism' is vexed. In reaction to the gloomy forecasts of the environmental movement in the latter part of the 20th C, positive views were put forward that various environmental concerns were not as bad as had been portrayed [55,56], and the theme was taken up by Bjørn Lomborg [57,58]. In 2015, the ecomodernist manifesto was published which favoured the intensifying of agriculture and fossil energy extraction, the manufacture of synthetic foods, aquaculture and denser urbanization, ostensibly to give more room for nature [59]. Steven Pinker [60] then relied on references to the Enlightenment to justify his similar belief in more such progress and was critical of environmentalists for their 'primitive intuitions'. Hans Rosling [61] also regarded the prevailing view of the world as unduly pessimistic, drawing attention to life expectancy, disease incidence, global poverty, etc., all showing improvement contrary to popular perception.

Much obvious progress has been made in public health, but not in reducing extreme poverty, which is often defined as a per capita income below USD 1.90 per day (equivalent to 35 people in Britain subsisting on a single minimum wage). At the more realistic World 
Bank threshold of USD 7.40 per day, the world has $4.2 \mathrm{bn}$ poor people, or six times more than those below USD 1.90 per day [62]. According to the Yale philosopher Thomas Pogge, the morally relevant metric of progress in eliminating poverty is not absolute numbers, proportions or trends, but the extent of poverty compared to our capacity to end it, by which yardstick the world is doing worse than ever.

Much such optimism recalls orthodox economics, or at least an acceptance of continuing growth. For instance, ecomodernism equates poverty to a lack of modernization so that the solution is simply more modernization, making it something universal to which all right-thinking people should be committed [63].

\section{Optimism and the UN}

The Kyoto Protocol only ever gave the illusion of action and 'relentless optimism was the order of the day' [3]. The vision underpinning the UN Framework Convention on Climate Change, the Kyoto Protocol and the Stern Review demanded a degree of optimism unfounded on the evidence [38].

Over decades, and always having the effect of prolonging climate delay, the UN admitted Integrated Assessment Models that muddled economics with science to give self-defeating market-based policy, then added carbon sinks to carbon budgets (which countenanced offsetting), then favoured carbon capture and storage, then bioenergy with carbon capture and storage, then mass tree planting, then overshoot with direct air capture later and soon geoengineering. As 'the mirage of each magical technical solution disappeared, another equally unworkable alternative took its place. They are all no more than fairy tales' [64].

The Executive Secretary to the UN Framework Convention on Climate Change, Patricia Espinosa, says that climate projections showing that the world is seriously off-target are helpful in illustrating the gravity and urgency of the situation, and the rapid response to the Covid-19 pandemic offers hope of a breakthrough. She continues: 'The UN stresses the need to increase ambition, talking to governments without interruption and without pointing fingers, just reminding everyone that this is a collective obligation' [65].

The UN has been saying much the same thing for 50 years; it has the merit of being well-meaning.

\section{Global Optimism}

Global Optimism is an organization founded by Christiana Figueres, Patricia Espinosa's predecessor, and her political adviser, Tom Rivett-Carnac. Their aim is 'to harness the energy of outrage and the possibility of optimism' to bring about environmental and social change. In their recent book [66], they say that we have the unique chance to create a future where things not only stabilize, but get better: 'We can have more efficient and cheaper transportation resulting in less traffic; we can practise smarter use of natural resources resulting in less pollution; we have most if not all of the technologies that we will need; we have the necessary capital; and we know which policies are most effective. And we are still, just barely, inside a zone where we can stave off the worst' [66]. According to this prospectus, there is little to worry about.

The authors give little weight to the continuing increase in greenhouse gas emissions and the evidence of climate breakdown, and do not address the continuing growth in rich countries. It is obvious that saying it is too late to act would lead to fatalism, but that 'we can still stave off the worst' is easily interpreted as coded licence for delay and complacency. Dwelling on the future in this way is also a way of ignoring the present, or what specifically could be done now.

Christiana Figueres previously made her outlook more explicit: 'Three unstoppable forces are pushing us towards a future of prosperity, growth and clean energy: climate leadership, market forces and the digital revolution [67]. 
Global Optimism's interpretation of optimism is distinguished by the oxymoronic character of its aim, to reconcile optimism with outrage. Outrage without optimism is said to lead to defeatism, but that is incorrect; if unaddressed, outrage leads to civil unrest.

\section{Optimism and the Prospect of Hardship}

Most social scientists (and no doubt many others) have known nothing but stability and are therefore blind to the prospect of disaster [68]. However, fifty years ago Dennis Meadows and colleagues projected that industrial output and agricultural production would begin to fall sometime in the period 2010-2050, leading to a decline in the human population to around half the then current number (i.e., to about 2bn) [69]. Ten years ago, it was increasingly likely that warming will continue to $4{ }^{\circ} \mathrm{C}$ or beyond, and that the consequent impacts would probably be incompatible with an organized global community [70]. Hans Joachim Schellnhuber, one of the world's leading climate scientists, is quoted as saying that the difference between $2{ }^{\circ} \mathrm{C}$ and $4{ }^{\circ} \mathrm{C}$ of warming 'is human civilization' [71], and at $5{ }^{\circ} \mathrm{C}$ warming the human population would decrease to fewer than $1 \mathrm{bn}$ [72].

In addition, intergroup violence increases with environmental stress, competition for resources and habitable land [73-75]. All civilized sophistication could collapse if carrying capacity is everywhere lowered by climate change [76]. In the US, for every $1{ }^{\circ} \mathrm{C}$ rise in average temperature, cases of assault and murder are predicted to increase by 24,000 per year [34]. Riots attributable to increasing social inequality are spreading to formerly peaceful countries [77]. And civil unrest within countries may also increase as trust in national institutions is lost [78].

Among the small minority of people in Britain who openly accept that such decline and hardship are inevitable (apart from those whose dwellings have fallen into the sea or are repeatedly flooded), are those in the cultural movement known as the Dark Mountain Project whose manifesto says that environmentalists are not being honest, environmental campaigns are not working and public life and the world of culture are permeated by a refusal to face reality [79]. Far from bringing about despair, supporters are said to have found relief and renewed hope in its frankness, having formerly been 'going through the motions of saving the planet'. The campaigning movement Dark Optimism, founded by Shaun Chamberlin and influenced by David Fleming [80], agrees that a dark immediate future is to be faced with belief in humanity and the kind of world it could create, and Jem Bendell has attracted substantial popular interest by expressing similar views in blunt language [81].

These examples of relief and hope have limits, however, curiously leapfrogging the expected descent into violence and suffering to a relatively benign post-collapse era. Apart from being remote, this prospect assumes that humanity will indeed reform itself, but it might not. Humans may only have begun farming once the megafauna (mammoth, wild ancestors of cattle and equines, etc.) had been hunted to extinction [82], and the advent of democracy was largely due to the increasing use of fossil fuels not to any general human improvement [83]. In the science fiction novel A Canticle for Liebowitz, war followed war until the Earth was ruined [84].

With such violence in the back of the mind, to concentrate on a benign future, however distant, avoids any accusation of tactlessness or self-fulfilling prophesy, but without any such preoccupation hardship (or rather transformative change) has been openly contemplated in three ways. First, in his 2020 TED talk, Mr Rivett-Carnac advocates 'stubborn optimism', the facing of (unpalatable) facts so unflinchingly as to give rise to determined and sustained action. This is more similar to stoicism than anything to do with optimism, and is not consistent with the outlook of his employer, the UN. Secondly, there are moral obligations other than obedience to the law [85]; the philosopher Andreas Malm [86] identifies an itching feeling to 'physically cut off the combustion of fossil fuels, deflate the tyres and block the runways'. And many young people would have let Covid-19 run its course among the older generation [87], whom they see as patronizing them and caring less about the future than they do (cited in [88]). 


\section{Conclusions}

Climate change inaction is not difficult to understand, and its logical basis is correctly identified as a tragedy of the commons. This has proved to be inconsequential, but does not mean that continued inaction is 'wicked' or insoluble.

In rich countries, the public is accused of such frailty that it must be shielded from the realities of climate change and the prospect of constraints to its profligate lifestyle, but there seems to be no evidence for this, and in any case, inaction cannot be made worse without meaningful action in the first place. Optimism is invoked to help justify the shielding, ostensibly to overcome public fatalism and inaction, but instead it amounts to the suppression of truth (and often recalls the outlook of orthodox economics). In consequence, the gap between public perception and scientific reality, already enormous a decade ago [89], is now wider than ever. The practical effect is to prolong climate delay.

Advocates of shielding and optimism take their lead from national governments and the UN. The UK government's devices are devious (and thus it understands them to be disreputable), a point made by a cartoon on the website of the Alliance of World Scientists. It shows a lecturer standing at a board bearing words: 'Research concludes WE ARE DESTROYING THE EARTH'. An onlooker representing government asks: 'Could you rephrase that in equivocal, inaccurate, vague, self-serving and roundabout terms that we can all understand'?

In her TED talk of 2016, Christiana Figueres refers to her work in creating a mood of positivity at the Paris conference, which she says was helpful, but in what could be interpreted as a logical error, the need for optimism is taken to apply not just to UN conferences but to everyone else, particularly a recalcitrant public. This disregards the hierarchical (holistic) nature of society, namely that what is appropriate at one level need not be at another.

Telling the public to be positive must please those with interests vested in businessas-usual. 'The smart way to keep people passive ... is to strictly limit the spectrum of acceptable opinion but allow very lively debate within that spectrum-even encourage the more critical and dissident views' [90]. Governments are exhorted to do more, which is to advocate for incremental change, but the gap between what is being done and what needs to be done is widening and cannot be remedied with more money or greater efforts. Any transformational change to way of life to reduce energy demand, let alone the prospect of hardship, is not part of the discourse.

Few say openly that the UN process of climate conferences and accords is too slow to be effectual, or that the Intergovernmental Panel on Climate Change (a body that exists to respect evidence with rigour) should not be institutionally optimistic, or that the UN's Sustainable Development Goals are self-contradictory. Perhaps this is because the agencies funding climate science (and much other scholarship) create a systemic bias towards confining conclusions to the boundaries of the status quo [91]. Perhaps the UN cannot be expected to criticize its own processes, which according to Mr Rivett-Carnac (in his 2020 TED Talk), proceed at the speed glaciers used to move at. Perhaps Mahatma Gandhi was wrong when he said 'truth never damages a cause that is just'.

Funding: This research received no external funding.

Acknowledgments: I thank Jerry Ross and Pablo Jourdan for constructive comments on early versions of this article.

Conflicts of Interest: The author declares no conflict of interest.

\section{References}

1. Edmunds, D.; Eidinow, J. Wittgenstein's Poker; Faber \& Faber: London, UK, 2001.

2. Hulme, M. Is it too late (to stop dangerous climate change)? An editorial. Wiley Interdiscip. Rev. Clim. Chang. 2020, 11, e619. [CrossRef]

3. Prins, G.; Rayner, S. The Wrong Trousers: Radically Rethinking Climate Policy; Joint Discussion Paper; James Martin Institute, University of Oxford and MacKinder Centre, London School of Economics: London, UK, 2007. 
4. Rittel, H.W.J.; Webber, M.M. Dilemmas in the general theory of planning. Policy Sci. 1973, 4, 154-159. [CrossRef]

5. Bardi, U. Before the Collapse: A Guide to the Other Side of Growth; Springer: Cham, Switzerland, 2020.

6. Passioura, J.B. Accountability, philosophy and plant physiology. Search 1979, 10, 347-350.

7. Ostrom, E. Governing the Commons: The Evolution of Institutions for Collective Action; CUP: Cambridge, UK, 2015.

8. Singer, E. Game theory calls cooperation into question. Quanta Magazine, 12 February 2015. Available online: https://tinyurl.co $\mathrm{m} /$ hdn6vumw (accessed on 12 July 2021).

9. Aklin, M.; Mildenberger, M. Prisoners of the Wrong Dilemma: Why Distributive Conflict, Not Collective Action, Characterizes the Politics of Climate Change. Glob. Environ. Polit. 2020, 20, 4-27. [CrossRef]

10. MacKay, D.J.C. Sustainability-Without the Hot Air; UIT: Cambridge, UK, 2009.

11. Hardin, G. The Tragedy of the Commons. Science 1968, 162, 1243-1248. [CrossRef] [PubMed]

12. Diamond, J. Collapse: How Societies Choose to Fail or Succeed; Penguin Books: London, UK, 2005.

13. Fairlie, S. A short history of enclosure in Britain. The Land 2009, 7, 16-31.

14. Binmore, K. Game Theory: A Very Short Introduction; OUP: Oxford, UK, 2007.

15. Hale, T. Catalytic Cooperation. Glob. Environ. Polit. 2020, 20, 73-98. [CrossRef]

16. Dunbar, R.; Zebrowski, C.; Olsson, P. Is humanity doomed because we can't plan for the long term? Three experts discuss. The Conversation, 5 August 2020. Available online: https: / / tinyurl.com/k87jjqlx (accessed on 12 July 2021).

17. Wolpert, L. Six Impossible Things before Breakfast: The Evolutionary Origins of Belief; Faber \& Faber: London, UK, 2006.

18. Gould, S.J. How the Vulva Stone Became a Brachiopod. In The Lying Stones of Marrakech: Penultimate Reflections in Natural History; Three Rivers Press: New York, NY, USA, 2000; pp. 53-74.

19. Klintman, M. Knowledge Resistance: How We Avoid Insight from Others; Manchester University Press: Manchester, UK, 2019.

20. Lehrer, J. How We Decide; Houghton Mifflin Harcourt: Boston, MA, USA, 2009.

21. Taber, C.S.; Lodge, M. Motivated Skepticism in the Evaluation of Political Beliefs. Am. J. Polit. Sci. 2006, 50, 755-769. [CrossRef]

22. Daly, H.E.; Cobb, J.B., Jr. For the Common Good: Redirecting the Economy toward Community, the Environment and a Sustainable Future; Beacon Press: Boston, MA, USA, 1994.

23. Gardiner, S.M. A Perfect Moral Storm: The Ethical Tragedy of Climate Change; OUP: Oxford, UK, 2011.

24. Rowlatt, J. India climate: What do drowning rhinos and drought tell us? BBC News, 6 August 2016. Available online: www.bbc.co .uk/news/world-asia-india-36989173 (accessed on 12 July 2021).

25. Jackson, T. Prosperity without Growth? The Transition to a Sustainable Economy; Sustainable Development Commission: London, UK, 2009.

26. McGrath, M. Caution urged over use of 'carbon unicorns' to limit warming. BBC News, 5 October 2018. Available online: www.bbc.co.uk/news/science-environment-45742191 (accessed on 12 July 2021).

27. Wallace-Wells, D. The war on climate denial has been won. And that's not the only good news. New York Magazine/Aeon, 19 January 2021. Available online: https:/ / tinyurl.com/yyqtc4cg (accessed on 12 July 2021).

28. Weber, E.U. Experience-Based and Description-Based Perceptions of Long-Term Risk: Why Global Warming does not Scare us (Yet). Clim. Chang. 2006, 77, 103-120. [CrossRef]

29. Black, R.; Happer, C. Climate crisis: Keeping hope of $1.5^{\circ} \mathrm{C}$ limit alive is vital to spurring global action. The Conversation, 30 March 2021. Available online: https:/ / tinyurl.com/dkpcpm28 (accessed on 12 July 2021).

30. Evans, S. The Carbon Brief interview: Chris Stark. Carbon Brief, 12 July 2018. Available online: https://tinyurl.com/ks74d4zk (accessed on 12 July 2021).

31. Greenfield, P. Don't look away now: Are viewers finally ready for the truth about nature? The Guardian Newspaper, 9 September 2020. Available online: https:/ / tinyurl.com/y4dq4jdp (accessed on 12 July 2021).

32. Rayner, T.; Minns, A. The Challenge of Communicating Unwelcome Climate Messages; Working Paper 162; Tyndall Centre for Climate Change Research, University of East Anglia: Norwich, UK, 2015.

33. Wallace-Wells, D. The Uninhabitable Earth. Famine, economic collapse, a sun that cooks us: What climate change could wreakSooner than you think. New York Magazine, 9 July 2017. Available online: https://tinyurl.com/3y946w8p (accessed on 12 July 2021).

34. Doherty, T.J.; Clayton, S. The psychological impacts of global climate change. Am. Psychol. 2011, 66, 265-276. [CrossRef] [PubMed]

35. Stoknes, P.E. What We Think about When We Try Not to Think about Global Warming: Toward a New Psychology of Climate Action; Chelsea Green: White River Junction, VT, USA, 2015.

36. Macy, J.; Brown, M.Y. Coming Back to Life: Practices to Reconnect Our Lives, Our World; New Society Publishers: Gabriola Island, BC, Canada, 1998.

37. Hopkins, R. Lise Van Susteren on pre-traumatic stress disorder and the imagination. Rob Hopkins, 24 April 2018. Available online: www.robhopkins.net/2018/04/24/847/ (accessed on 12 July 2021).

38. Hulme, M. The conquering of climate: Discourses of fear and their dissolution. Geogr. J. 2008, 174, 5-16. [CrossRef]

39. McGuire, B. An Alarmist's Guide to Climate Change; Scientists for Global Responsibility: Preston, UK, 2019.

40. Meadows, D. How environmentalists ought to talk. Global Citizen, 29 February 1996. Available online: https://tinyurl.com/yepe hee4 (accessed on 12 July 2021).

41. O'Neill, S.J.; Nicholson-Cole, S. 'Fear won't do it': Promoting positive engagement with climate change through imagery and icons. Sci. Commun. 2009, 30, 355-379. [CrossRef] 
42. Myers, G.; Macnaghten, P. Rhetorics of Environmental Sustainability: Commonplaces and Places. Environ. Plan. A Econ. Space 1998, 30, 333-353. [CrossRef]

43. Moser, S.C.; Dilling, L. Making Climate HOT. Environ. Sci. Policy Sustain. Dev. 2004, 46, 32-46. [CrossRef]

44. HoC. Select Committee on Environment, Food and Rural Affairs-Eighth Report; House of Commons, HM Government: London, UK, 2007.

45. Lamb, W.F.; Mattioli, G.; Levi, S.; Roberts, J.T.; Capstick, S.; Creutzig, F.; Minx, J.C.; Müller-Hansen, F.; Culhane, T.; Steinberger, J.K. Discourses of climate delay. Glob. Sustain. 2020, 3, e17. [CrossRef]

46. Giddens, A. The Politics of Climate Change, 2nd ed.; Polity Press: Cambridge, UK, 2011.

47. Helm, D. The Carbon Crunch: Revised and Updated; Yale University Press: New Haven, CT, USA, 2015.

48. Victor, D.G. Global Warming Gridlock: Creating More Effective Strategies for Protecting the Planet; CUP: Cambridge, UK, 2011.

49. Rankin, J. EU climate goals 'just a collection of buzzwords' say critics. The Guardian Newspaper, 10 June 2019. Available online: https:/ / tinyurl.com/svctprm (accessed on 12 July 2021).

50. Watt, R. Carbon offsets offer a fantasy of capitalism without crises. The Conversation, 12 March 2021. Available online: https: / / tinyurl.com/xhyxkak (accessed on 12 July 2021).

51. Kapoor, I. Psychoanalysis and development: Contributions, examples, limits. Third World Q. 2014, 35, 1120-1143. [CrossRef]

52. Sachs, J.D. The Age of Sustainable Development; Columbia University Press: New York, NY, USA, 2015.

53. Gallagher, B. The case for professors of stupidity: Why aren't there more people studying the science behind stupidity? Nautilus, 30 January 2019. Available online: https: / tinyurl.com/sfbzkpp (accessed on 12 July 2021).

54. Andrews, H. Boomers: The Men and Women Who Promised Freedom and Delivered Disaster; Sentinel: New York, NY, USA, 2021.

55. Easterbrook, G. A Moment on the Earth: The Coming Age of Environmental Optimism; Penguin Books: New York, NY, USA, 1995.

56. North, R.D. Life on a Modern Planet: A Manifesto for Progress; Manchester University Press: Manchester, UK, 1995.

57. Lomborg, B. The Skeptical Environmentalist: Measuring the Real State of the World; CUP: Cambridge, UK, 2001.

58. Lomborg, B. Cool It: The Skeptical Environmentalist's Guide to Global Warming; Alfred A. Knopf: New York, NY, USA, 2007.

59. Asafu-Adjaye, J.; Blomqvist, L.; Brand, S.; Brook, B.; DeFries, R.; Ellis, E.; Foreman, C.; Keith, D.; Lewis, M.; Lynas, M.; et al. An Ecomodernist Manifesto. 2015. Available online: www.ecomodernism.org (accessed on 3 April 2021).

60. Pinker, S. Enlightenment Now: The Case for Reason, Science, Humanism and Progress; Penguin: London, UK, 2018.

61. Rosling, H. Factfulness: Ten Reasons We're Wrong about the World-And Why Things Are Better than You Think; Sceptre Books: London, UK, 2019.

62. Hickel, J. Progress and its discontents. New Internationalist, 7 August 2019. Available online: https://tinyurl.com/y27a2zsk (accessed on 12 July 2021).

63. Smaje, C. Dark Thoughts on Ecomodernism. The Dark Mountain Project. 2015. Available online: https://tinyurl.com/8mc3nwcs/ (accessed on 3 April 2021).

64. Dyke, J.; Watson, R.; Knorr, W. Climate scientists: Concept of net zero is a dangerous trap. The Conversation, 22 April 2021. Available online: https:/ / tinyurl.com/2rj48spd (accessed on 12 July 2021).

65. Vaughan, A. UN climate chief Patricia Espinosa: We can still turn this around. New Scientist, 24 April 2021. Available online: https: / / tinyurl.com/4wk8zwnp (accessed on 12 July 2021).

66. Figueres, C.; Rivett-Carnac, T. The Future We Choose: Surviving the Climate Crisis; Manilla Press: London, UK, 2020.

67. Falk, J.; Gaffney, O.; Bhowmik, A.K.; Borgström-Hansson, C. Exponential Climate Action Roadmap; Future Earth: Stockholm, Sweden, 2018.

68. Welzer, H. Climate Wars: What People Will Be Killed for in the 21st Century; Polity Press: Cambridge, UK, 2017.

69. Meadows, D.H.; Meadows, D.L.; Randers, J.; Behrens, W.W., III. The Limits to Growth: A Report for the Club of Rome's Project on the Predicament of Mankind; Universe Books: New York, NY, USA, 1972.

70. Anderson, K.; Bows, A. Beyond 'dangerous' climate change: Emission scenarios for a new world. Philos. Trans. R. Soc. A 2011, 369, 20-44. [CrossRef] [PubMed]

71. Edwards, D.; Cromwell, D. Propaganda Blitz: How the Corporate Media Distort Reality; Pluto Press: London, UK, 2018.

72. Kanter, J. Scientist: Warming could cut population to 1 billion. The New York Times, 13 March 2009. Available online: https: / / tinyurl.com/yx5ssg5r (accessed on 12 July 2021).

73. Hsiang, S.M.; Meng, K.C.; Cane, M.A. Civil conflicts are associated with the global climate. Nature 2011, 476, 438-441. [CrossRef] [PubMed]

74. Homer-Dixon, T.F.; Boutwell, J.H.; Rathjens, G.W. Environmental change and violent conflict. Sci. Am. 1993, 268, 38-45. [CrossRef]

75. Galgano, F.A. The Environment-Conflict Nexus. In The Environment-Conflict Nexus: Climate Change and the Emergent National Security Landscape; Galgano, F., Ed.; Springer: Cham, Switzerland, 2019; pp. 1-18.

76. LeBlanc, S.A.; Register, K.E. Constant Battles: The Myth of the Peaceful, Noble Savage; St Martin's Press: New York, NY, USA, 2003.

77. Kukis, M. Unrest in your backyard. Aeon, 5 January 2021. Available online: https://tinyurl.com/y6gvhy9k (accessed on 12 July 2021).

78. Abbott, C. An Uncertain Future: Law Enforcement, National Security and Climate Change; Oxford Research Group: London, UK, 2008.

79. Kingsnorth, P. Why I stopped believing in environmentalism and started the Dark Mountain Project. The Guardian Newspaper, 29 April 2010. Available online: https:/ / tinyurl.com/ugo4cwo (accessed on 12 July 2021).

80. Fleming, D. Lean Logic: A Dictionary for the Future and How to Survive It; Chelsea Green: White River Junction, VT, USA, 2016. 
81. Bendell, J. Deep Adaptation: A Map for Navigating Climate Tragedy; IFLAS Occasional Paper 2; Institute of Leadership and Sustainability, University of Cumbria: Carlisle, UK, 2018.

82. Longrich, N. How the extinction of ice age mammals may have forced us to invent civilization. The Conversation, 3 January 2020. Available online: https: / tinyurl.com/yg45tdll (accessed on 12 July 2021).

83. Malm, A. Fossil Capital: The Rise of Steam Power and the Roots of Global Warming; Verso Books: London, UK, 2016.

84. Miller, W.M., Jr. A Canticle for Liebowitz; Orbit: London, UK, 1959.

85. Hamilton, C. Requiem for a Species: Why We Resist the Truth about Climate Change; Routledge: Abingdon, UK, 2010.

86. Malm, A. The Progress of This Storm: Nature and Society in a Warming World; Verso Books: London, UK, 2018.

87. Agar, N. How Covid-19 and climate change mirror each other. Ideas Room, 16 March 2020. Available online: https://tinyurl.com/ y8f5qdsp (accessed on 12 July 2021).

88. Rauch, M. Interview: Lise Van Susteren talks about the mental health impacts of climate change. Moms Clean Air Force, 13 October 2017. Available online: https:/ / tinyurl.com/vqasf2u (accessed on 12 July 2021).

89. Hansen, J. Storms of My Grandchildren: The Truth about the Coming Climate Catastrophe and Our Last Chance to Save Humanity; Bloomsbury: London, UK, 2009.

90. Chomsky, N. The Common Good; Pluto Press: London, UK, 2003.

91. Anderson, K. Turning Delusion into Climate Action; Responsible Science No. 2; Scientists for Global Responsibility: Preston, UK, 2020. 